\title{
HOMENAJE A DON LUIS ASTEY
}

Ruy Pérez Tamayo*

\section{Quisiera explicar mi presencia hoy} aquí. Yo no conocí a Don Luis Astey hasta que ingresó a la Academia Mexicana en 1993, y como parte de 1955 estuve fuera de México, me perdí su discurso de ingreso a nuestro cuerpo colegiado. Recuerdo que al principio siempre lo veía llegar a las sesiones regulares de la Academia cargando un pequeño envoltorio o una bolsa de plástico conteniendo libros, que después me enteré los adquiría en las librerías "de viejo" cercanas al edificio de la Academia, en la calle de Donceles, a las que acudía cada segundo y cuarto jueves del mes, que es cuando se llevan a cabo nuestras sesiones regulares. Como yo hacía y sigo haciendo lo mismo ( $\mathrm{y}$ también lo hacían otros académicos más, como los recientemente desaparecidos Fernando Salmerón y Roberto Moreno de los Arcos, y lo siguen haciendo otros, como los felizmente vivos Andrés Henestrosa y Ali Chumacero), pronto desarrollé la práctica de intercambiar inspecciones de nuestras respectivas compras librescas, mientras esperábamos que llegaran los miembros faltantes para hacer quorum e iniciar la sesión formal de la Academia. Recuerdo mi asombro inicial ante los títulos que escogía Don Luis, comparados con los míos: cuando él había adquirido un ejemplar de Primeros planos de la Catedral de San Luis Potosí, edición de la SEP de 1951, o Tierra y libertad: política agraria en Morelos, impreso por Editorial Patria en 1978, yo había comprado La reliquia y La ciudad y la sierra,

* Facultad de Medicina, UNAM. 
RUY PÉREZ TAMAYO

de Eça de Queiroz, de la Editorial Botas, de 1947, para regalárselos a algunos jóvenes y buenos amigos que no habían tenido el privilegio de conocer y disfrutar a ese milagroso escritor portugués.

La característica sobresaliente de Don Luis en la Academia (que es donde yo lo ví siempre) es que no hablaba. No decía absolutamente nada. Nunca. Asistía regularmente, llegaba temprano, se sentaba sonriente y con actitud benigna en la oficina donde nos reunimos los académicos hasta que haya quorum, para después subir a nuestra sala de juntas (un amplio espacio, ocupado casi totalmente por una gran mesa en donde descansan varias docenas de diccionarios del idioma español de todos tipos, junto con muchos otros libros), y sistemáticamente ocupaba la silla a mi izquierda (la de mi derecha pertenecía a Fernando Salmerón, y desde su sentida ausencia la ocupa Don Eulalio Ferrer). Como académico, Don Luis fue un miembro impecable, pero también insondable, porque casi nunca en sus escasos cuatro años de pertenencia a la Academia, hizo algún comentario espontáneo sobre tema alguno. Cuando se le interrogaba directamente sobre un punto relacionado con su especialidad, respondía con brevedad, en voz baja y con un tono casi apologético.

160 Pero yo tuve el privilegio de establecer un contacto personal con Don Luis, un contacto no técnico, no académico ni profesional, sino humano. La lotería de la vida determinó que el hijo Gabriel de Don Luis se enamorara de mi nieta Amandita. Debo decirles que para mí este hecho confirmó la inteligencia y el buen gusto de los genes de Don Luis, porque mi nieta Amandita es preciosísima, y cualquier chavo que así lo perciba tiene mis respetos. Yo me enteré porque un día Don Luis, antes de iniciarse la sesión de la Academia, me dijo sonriente y casi en secreto: "Ya conocí a Amandita...." Mi sorpresa fue doble, pues por un lado Don Luis me había hablado espontáneamente, cosa inusitada, pero por otro lado, había hecho referencia a mi nieta. Al mismo tiempo que la relación se aclaró y que disminuyó mi sorpresa, aumentó mi simpatía por Don Luis, de quien desde entonces me sentí casi pariente. A partir de ese momento nuestros encuentros en la Academia fueron cordiales y afectuosos, aunque, el número de frases que 
intercambiamos no aumentó mucho, en gran parte debido a la proverbial parsimonia verbal de Don Luis. Cuando supe de la enfermedad que finalmente terminó con su vida me sorprendí de lo bien que se veía, a pesar de que estaba ya en un estado muy avanzado. Nunca nos dijo nada al respecto, y sólo se ausentó de la Academia pocas semanas antes de morir. Los miembros de la Academia lo extrañamos, y yo especialmente echo de menos su figura pequeña, tranquila y benigna, vestida de negro, con su corbata mal puesta, su gesto amable y atento, y especialmente su silencio. Descanse en paz mi buen amigo y casi pariente Don Luis. 